Jurnal Konstruksi Hukum | ISSN: XXXX | E-ISSN: XXXX Vol. 1, No. 1, September 2020 Hal. 176-180| Available online at https://www.ejournal.warmadewa.ac.id/index.php/jukonhum

DOI: https://doi.org/10.22225/jkh.1.1.2246.176-180

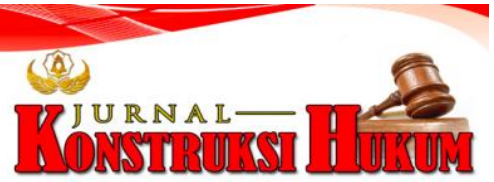

\title{
AKIBAT HUKUM JUAL BELI DI BAWAH TANGAN ATAS TANAH HAK MILIK DI KABUPATEN BADUNG
}

\author{
I Gusti Agung Ayu Lita Pratiwi, Nella Hasibuan Oleary, Ni Made Puspasutari Ujianti \\ Fakultas Hukum Universitas Warmadewa, Denpasar-Bali, Indonesia
}

\begin{abstract}
Abstrak
Transaksi jual beli di Kabupaten Badung yang dibuat oleh kedua belah pihak berupa perjanjian dibawah tangan, tetapi salah satu pihak melakukan tindakan ingkar janji atau bias disebut dengan wanprestasi. Tujuan dari penelitian ini untuk mengetahui konsekuensi hukum dari jual beli dibawah tangan atas kepemilikan tanah di Kabupaten Badung. Metode penelitian ini menggunakan jenis penelitian hukum empiris. Dalam praktiknya, pelaksanaan pembelian yang mengikat dan pembelian di masyarakat dibawah hak kepemilikan tanah sering dilakukan oleh beberapa pihak, salah satunya terjadi di Kabupaten Badung. Praktek jual beli tanah yang dilakukan secara di bawah tangan tidak sesuai dengan peraturan pemerintah Nomor 24 Tahun 1997 tentang Pendaftaran Tanah, yang mengharuskan jual beli dibuat dengan akta otentik, dan bukan di bawah tangan. Namun, proses jual beli di Kecamatan Lukluk, Kecamatan Mengwi, Kabupaten Badung masih berlaku bagi mereka yang menandatangani akta tersebut, karena pemenuhan persyaratan hukum untuk jual beli di bawah UUPA bersifat material, formal dan tunai, jelas dan sungguh. Pada prinsipnya, dalam perjanjian penjualan baik dibawah tangan dan notarisakan dianggap sah sebagai hukum bagi mereka yang membuatnya. Dan juga menurut pasal $1320 \mathrm{KUH}$ Perdata menyatakan validitas suatu perjanjian jika, antara lain: Adanya suatu perjanjian, keterampilan, hal tertentu, dan sebab-sebab yang sah. Dan meskipun dianggap sah dengan memenuhi persyaratan menurut pasal $1320 \mathrm{KUH}$ Perdata, penjualan dan pembelian tanah masih harus di lakukan sebelum otoritas yang berwenang (PPAT).
\end{abstract}

Kata Kunci: Akibat hukum; Jual beli; Tanah hak milik

\begin{abstract}
The sale and purchase transaction in Badung Regency which was made by both parties was in the form of an agreement of hands, but one of the parties who broke a promise or could be called a default. The purpose of this research is to see the legal dangers of underhand trading on land ownership in Badung Regency. This research method uses empirical legal research. In practice, the implementation of binding purchases and purchases under land ownership rights is often carried out by several parties, one of which occurred in Badung Regency. The practice of buying and selling land carried out under the hand is not in accordance with government regulation Number 24 of 1997 concerning Land Registration, which requires that the sale and purchase be made with an authentic deed, and not under hand. However, the buying and selling process in Lukluk District, Mengwi District, Badung Regency is still ready for those who, the deed, because the fulfillment of the legal requirements for buying and selling under the UUPA is material, formal and cash, clear and sincere. In principle, in fine sales agreements and notaries will be a legal approach as law for them made. And also according to article 1320 of the Civil Code the validity of an agreement if, among others: There is an agreement, skills, certain matters, and valid reasons. And although according to lawful compliance with the requirements according to article 1320 of the Civil Code, the sale and purchase of land must be carried out before the prohibited authority (PPAT).
\end{abstract}

Keywords: Legal consequences; Sale and purchase; Freehold land

\section{PENDAHULUAN}

Tanah dan bangunan adalah kebutuhan utama manusia yang tak terhindarkan. Kebutuhan akan tanah akan meningkat seiring dengan pertumbuhan populasi, yang semuanya membutuhkan tanah untuk hidup dan melanjutkan kehid upan mereka (Badoa et al., 2018). Tanah memang merupakan asset kekayaan yang berharga. Apa lagi jika kondisinya strategis. Nilainya tumbuh secara signifikan dari waktu kewaktu. Bahkan saat ini, tanah telah menjadi salah satu instrument investasi untuk property yang diminati banyak orang karena harganya cenderung melonjak dari waktu kewaktu. Tanah berperan penting bagi kehidupan komunitas, disamping peran ekonomis yang dimiliki yang berfungsi 
mendukung kehidupan manusia dikemudian hari. Untuk membangun rumah, masyarakat melakukan proses jual beli tanah, yaitu komponen hukum perdata yang terdiri dari dua orang atau lebih terikat dimasa awal sepakat antara satu dengan lainnya.

Membeli dan menjual tanah sesuai dengan pasal 1457 KUH Perdata (selanjutnya disebut KUH Perdata) adalah perjanjian dimana satu pihak terikat untuk memberikan tanahnya pada pihak lainnya serta harus dibayar seharga yang disepakati. Dengan jual beli tidak ada perubahan pada hak atas tanah yang relevan, bahkan jika pembeli telah membayar harga penuh dan tanah telah secara fisik diserahkan kepadanya (Saranaung, 2017). Seharusnya ada cahaya dan uang tunai dalam penjualan dan pembelian tanah tradisional, cerah karena dilakukan sebelum kepala adat, sehingga diketahui oleh masyarakat.

Menurut undang-undang agraria, jual beli property non statis dalam bentuk tanah/bangunan seharusnya di adakan di hadapan Petugas Pembuatan Perbuatan Tanah (PPAT). Dengan berlakunya UUPA No. 5 tahun 1960. Pasal 26 UUPA menyatakan bahwa pembelian dan penjualan, pertukaran, pemberian, pemberian warisan, pemberian menurut adat dan tindakan lain yang dimaksudkan untuk mengalihkan kepemilikan dan kendali diatur oleh peraturan pemerintah. Ini berarti bahwa membeli dan menjual tanah tidak hanya merupakan tindakan bidang hukum perdata, tetapi terdapat juga dalam hukum publik (Fajaruddin, 2017). Berdasarkan pekerjaannya, terdapat beberapa hal yang mesti diberikan perhatian dalam pembuatan akta otentik sesuai dengan tugas utama pejabat untuk membuat catatan, yaitu membuat catatan otentik, ada sejumlah hal yang perlu dipertimbangkan (Pramono, 2015). Peraturan pejabat Pembuat Akta Tanah ditentukan oleh menteri memiliki tanggung jawab mengurusi masalah pertanahan (Rismayanthi, 2016). Jadi Pejabat Pembuat Akta Tanah akan menerima formulir akta yang telah ditetapkan. Akta pembelian dan pembelian Petugas Formasi Tanah ditentukan oleh menteri dalam perumusan standar, maka akta pembelian dan penjualan Aktor Pembelian Tanah adalah perjanjian standar.

Perundangan mendefinisikan hak milik sebagai hak secara berkesinambungan, terkuat, dan terlengkap yang dimiliki seseorang didarat dengan mempertimbangkan ketentuan Pasal 6 dengan ketentuan bahwa hak milik memiliki perbedaan dari hak lainnya. Pengaitan karakteristik ini tidak berarti bahwa hak itu mutlak, tidak terbatas dan tidak bias diganggu gugat. Kata herediter berarti hak untuk memiliki tanah tidak hanya berlangsung seumur hidup penerima, tetapi jika suatu kejadian hukum terjadi, kematian penerima dapat berlanjut melalui ahliwarisnya. Kata terkuat berarti bahwa hak atas tanah dapat di bebani dengan hak atas tanah lainnya, misalnya dibebani dengan Hak Guna Bangunan, Hak Guna Bangunan dan hak-hak lainnya. Hak milik atas tanah ini harus didaftarkan, sedangkan kata full berarti bahwa hak atas tanah telah memberikan hak yang luas kepada pemegang hak dalam hal penggunaan lahan mereka perjanjian tersebut dibuat dengan sistem tunai karena tindakan menyerahkan tanah dan pembayaran harga tanah dianggap terjadi secara simultan (simultan), yang berarti bahwa penjualan dan pembelian terpenuhi segera ketika tanah itu diserahkan (Hayati, 2016). Sifat uang tunai bukan merupakan rujukan langsung ke kondisi pembayaran secara penuh atau penuh. Namun, sebagai konsekuensi dari sifat kas, harga jual beli tanah dianggap telah dilunasi (meskipun hanya membayar sebagian saja), dan ini akan secara tegas dinyatakan dalam akta pembelian. PPAT tidak dimungkinkan untuk membuat Akta Jual Beli (selanjutnya disebut AJB) dengan ketentuan bahwa harga belum dibayar penuh yang secara tegas dinyatakan dalam akta. Jika pembayaran tentang pembayaran belum dinyatakan secara penuh dalam akta pembelian, maka itu tidak memenuhi unsur uang tunai, karena ini adalah uang tunai, itu berarti pembayaran harus dibayar penuh atau dianggap dibayar (Faranzenia et al., 2019). Hal lain, terlepas dari nama perjanjian jual beli, AJB yang dibuat oleh PPAT bukanlah perjanjian konsensual atau perjanjian wajib, tetapi tindakan hukum sebagai syarat pengungkit tanah. Akta jual beli yang dibuat oleh Petugas Pembentukan Akta Tanah ditentukan oleh Menteri dalam formulasi standar. Kemudian akta jual beli yang dilakukan oleh Aktor Pengambilan Tanah adalah perjanjian standar.

Berdasarkan uraia di atas, maka tujuan dari penelitian ini yakni untuk mengetahui konsekuensi hukum dari jual beli dibawah tangan atas kepemilikan tanah di Kabupaten Badung.

\section{METODE PENELITIAN}

Metode penelitian yang digunakan dalam penelitian ini yaitu Penelitian hukum empiris. Penelitian hukum empiris merupakan merupakan penelitian yang menggunakan data primer sebagai data utama (Soekanto, 2007). Data primer diperoleh dengan terjun langsung kelokasi data yang terkumpul 
kemudian dianalisis dengan deskriptif kualitatif. Teknik pengumpulan data dengan cara studi pustaka untuk mengumpulkan data sekunder berupa dokumentasi dan studi lapangan untuk mengumpulkan data primer dapat berupa wawancara berhadapan langsung dengan pejabat serta pihak pemberi informasi yang disebut juga informan. Data-data tersebut kemudian dikumpulkan, diolah, dianalisis berdasarkan argumentasi hukum yang di dapat melalui informan mengenai kasus yang sedang diteliti.

\section{HASIL DAN PEMBAHASAN}

Sahnya suatu akta atau perjanjian tidak ditentukan berdasarkan bentuk akta, tetapi ditentukan dari pemenuhan kondisi hukum Perjanjian (jika akta tersebut dalam bentuk perjanjian yang dibuat antara kedua pihak) (Harefa \& Tuhana, 2016). Tujuan suatu kesepakan adalah untuk pembentukan, perubahan atau penghentian suatu perjanjian. Perjanjian tersebut mensyaratkan (parapihak) untuk memberikan sesuatu, melakukan sesuatu, atau tidak melakukan sesuatu. Pada akhirnya, kewajiban itu harus ditentukan, tidak bias dibayangkan jika debitor tidak tahu apa kewajibannya dan kreditor tidak tahu apa haknya. Hakim akan bingung memutuskan apa yang harus dilakukan jika tidak diketahui apa yang telah dijanjikan diantara para pihak. Di masyarakat masih ada mereka yang melakukan perjanjian jual beli dibawah tangan salah satunya yang terjadi di Kabupaten Badung. Salah satu informasi diperoleh dari Bapak I Gusti Agung Surya Kusyanta, SH selaku Termohon yang membeli tanahnya di Desa Lukluk, Kecamatan Mengwi, Kabupaten Badung. Alasan untuk perjanjian jual beli dibawah tangan adalah: karena pembeli masih relative sehingga masih ada unsur saling percaya dan biaya yang diperlukan untuk melakukan proses jual beli sangat mahal dan tidak ada dana untuk membuat proses penggantian nama. Selain itu, lokasi objek tanah berada di Kabupaten Badung yang pajaknya cukup tinggi jika diproses dan belum mampu membayar biaya yang cukup mahal di PPAT (I Gusti Agung Surya Kusyanta, SH, Pembeli Pembeli, Wawancara Pribadi, Denpasar, 3 Januari 2020 pukul 13.05 WITA).

Jual beli tanah tidak dapat dipisahkan dari jumlah biaya, beberapa diantaranya secara resmi dibayarkan kepada negara atau pemerintah daerah dan ada juga biaya untuk pejabat yang melakukan jual beli, tetapi dapat di negosiasikan (Afriyandi, 2018). Menurut I Gusti Ketut Astawa, SH sebagai Notaris di Kabupaten Badung biaya yang timbul dari proses pembelian dan penjualan adalah: Biaya resmi seperti PPH, BPHTB, PNBP, sedangkan biaya lain seperti biaya untuk PPAT. Jual beli tanah dibawah tangan masih juga dilakukan salah satunya di Kabupaten Badung, hal ini karena tingkat kesadaran masyarakat masih rendah dan menganggap penggunaan sertifikat yang dibuat oleh PPAT, dianggap tidak terlalu penting bagi masyarakat dan jika ada adalah bagian besar dari mengelola sertifikat untuk kepentingan meminjam uang atau hutang. Dimana dalam melakukan pembayaran hutang harus ada hanya Debitur yang gagal bayar. Contoh masalah jual beli dibawah tangan yang diteliti terjadi di Desa Lukluk, Kabupaten Badung, yang dilakukan antara Pak I Nyoman Suarya selaku penjual dan Pak I Gusti Agus Surya Kusyanta, SH selaku pembeli, pembeli dan penjualan terjadi pada 27 Desember 2016. Kemudian, diuraikan bahwa kronologis jual beli dibawah tangan default, yaitu "Pada tanggal 27 Desember 2016 tuan I Nyoman Suarya melakukan transaksi jual beli tanah Hak Milik No. 1331/Lukluk, seluas 150m 2 kepada tuan I Gusti Agus Surya Kusyanta, SH yang manatran saksi tersebut tidak dilakukan di hadapan Notaris atau PPAT melainkan penjual dan pembeli sepakat untuk melakukan transaksi tersebut dengan membuat perjanjian dibawah tangan, dan belum melakukan proses balik nama menjadi atas nama tuan I Nyoman Agus Surya Kusyanta, SH.

Dalam melakukan proses jual beli tanah yang mereka lakukan sangat sederhana, yaitu terbatas untuk bertemu pembeli dan pembeli, maka ada diskusi dan kesepakatan seperti membeli dan menjual secara umum dengan menandatangani pembelian dan penjualan dibawah tangan. Biasanya sebagai bukti, sudah cukup dengan kwitansi, bahkan sering tidak diperkuat oleh saksi dari masing-masing pihak. Pengalihan hak tersebut masih harus mensyaratkan adanya tindakan hukum lain dalam bentuk penyerahan (leevering) dan akta dibuat oleh pejabat untuk mentransfer nama, jadi pada dasarnya, sebelum topi dilakukan atas nama tanah dapat belum di transfer kepembeli. Dan setelah terjadinya salah satu pihak melakukan wanprestasi yang berlatar belakang jual beli dibawah tangan. Pada setiap kejadian selalu diberikan arahan tentang keharusan mendaftarkan di hadapan PPAT atau notaris. Penjual dan pembeli menjadi syarat utama ketika akan mengadakan perjanjian. Dimana keduanya yang mengadakan perjanjian pembelian dan pembelian harus mematuhi isi perjanjian yang dibuatnya. Hal yang perlu diberi penekanan agar mereka terampil dalam bertransaksi tersebut. Ini berarti penjual dan pembeli diasumsikan orang dewasa berdasarkan perundangan dan tidak diawasi. Pada saat 
membuatnya, mereka bias melakukannya dengan bebas dalam hal ketentuan bentuk dan isinya yang dibuat.

Tahap selanjutnya setelah para pihak sepakat akan dibuat konsep atau kesepakatan. Ada 2 jenis perjanjian yaitu perjanjian curang dan perjanjian yang dibuat sebelum pejabat yang berwenang, jika perjanjian dibuat sebelum pejabat yang berwenang, dua lembar akta akan dibuat, Lembar kedua akan diserahkan ke kantor pertanahan setempat dan lembar pertama akan disimpan dikantor PPAT sebagai minuta, sementara perjanjian yang dibuat dibawah tangan juga harus dihadiri oleh saksi minimal 2 (dua) saksi untuk berpartisipasi dalam penandatanganan perjanjian yang diperlukan oleh saksi karena kekuatan hukum perjanjian berdasarkan tangan tidak sekuat akta otentik atau perjanjian yang dibuat sebelum pejabat yang berwenang. Berkenaan dengan penggunaan saksi sebagai bukti, Pasal 1905 KUH Perdata bahwa hanya ada satu saksi tanpa alat bukti lain dipengadilan yang tidak dipercaya. Karena itu, fungsi saksi dalam perjanjian pribadi adalah untuk memperkuat bukti jika terjadi perselisihan atas perjanjian tersebut. Dan setelah perjanjian tersebut selesai dibuat maka akan dibaca terlebih dahulu oleh para pihak agar sepakat atas isi perjanjian.

Berikutnya sesudah para pihak sepakat tentang isi perjanjian yang dibuat, para pihak akan menandatangani isi perjanjian yang telah disepakati. Fungsi tanda tangan dalam perjanjian adalah untuk memastikan identifikasi atau menentukan kebenaran karakteristik tandatangan. Pada saat yang sama, penandatanganan menjamin keberadaan konten yang terkandung dalam teks. Persyaratan penandatanganan juga ditegaskan dalam pasal 1869 KUH Perdata sampai 1874 KUH Perdata atau pasal 1 Ordonansi 1867 No. 29 Ketentuan-ketentuan pasal yang menekankan kekuatan akta tertulis dibawah tangan harus ditandatangani oleh para pihak. Secara hukum, surat bukti sempurna adalah instrument otentik, yaitu akta yang dilakukan dalam bentuk yang ditentukan oleh hukum oleh atau untuk petugas yang berwenang ditempatin strumen itu dibuat, misalnya, surat yang disusun oleh notaris.

Dalam kasus yang telah teliti itu bahwa perjanjian jual beli yang dilakukan dibawah tangan oleh tuan I Nyoman Suarya dengan tuan I Gusti Agus Surya Kusyanta, SH prestasinya yaitu mempunyai perjanjian jual beli dan wanprestasinya itu adalah tidak mempunyai kekuatan hukum sesuai ketentuan perundang-undangan menurut Pasal 37 PPNo. 24 tahun 1997 tentang pendaftaran tanah untuk melakukan proses peralihan hak atas jual beli tanah tersebut. Meskipun kekuatan membutikannya lemah, dan tak sempurna, akta dibawah tangan bias dijadikan alat bukti, namun ada pengecualiannya yaitu jika akta itu terdapat pembenaran dari pihak yang merasa rugi. Hal ini bias dilihat dari Yurisprudensi Mahkamah Agung No. 775K/Sip/1971, tanggal 06 Oktober 1971 yang kaidah hukumnya menyatakan: "Surat pembelian tanah" dibawah tangan" diajukan ke pengadilan, kemudian ditolak oleh pihak yang dirugikan, dan tidak dikonfirmasi dengan bukti lain, surat pembelian tanah dianggap sebagai bukti yang lemah dan tidak sempurna." Nilai bukti surat di bawah tangan lemah dan tidak sempurna, tetapi bisa menjadi bukti yang kuat dan sempurna jika diakui oleh pihak yang terluka atau diperkuat oleh bukti lain seperti pernyataan saksi, dll.

Demikian pelaksanaan jual beli dengan akta di bawah tangan tidak memiliki kekuatan hukum karena akta di bawah tangan di buat tanpa mematuhi ketentuan per Undang-undangan yang berlaku dan tidak dibuat dihadapan pejabat yang berwenang, dalam hal ini PPAT. Namun pihak yang dirugikan dalam pembuatan jual beli melalui akta di bawah tangan tersebut dapat melalui tuntutan di muka pengadilan apabila ada saksi-saksi yang menguatkan, sehingga ada keadilan bagi pihak yang dirugikan.

\section{SIMPULAN DAN SARAN}

\section{Simpulan}

Berdasarkan uraian di atas, dapat disimpulkan bahwa penyebab terjadinya jual beli tanah hak milik dibawah tangan adalah karena pembelinya masih merupakan keluarga dekat sehingga masih ada unsur saling percaya, biaya-biaya yang diperlukan untuk melakukan proses jual beli sangat tinggi. Praktek jual beli tanah yang dilakukan secara di bawah tangan tidak sesuai dengan peraturan pemerintah Nomor 24 Tahun 1997 tentang Pendaftaran Tanah, yang mengharuskan jual beli dibuat dengan akta otentik, dan bukan di bawah tangan. Namun, proses jual beli di Kecamatan Lukluk, Kecamatan Mengwi, Kabupaten Badung masih berlaku bagi mereka yang menandatangani akta tersebut, karena pemenuhan persyaratan hukum untuk jual beli di bawah UUPA bersifat material, formal dan tunai, jelas dan sungguh. Selain itu, jual beli telah memenuhi persyaratan jual beli sesuai dengan Pasal 1320 
KUHPerdata tentang kondisi hukum perjanjian. Namun, pengalihan hak atas tanah harus dilakukan sebelum PPAT sehingga penjualan dan pembelian tanah dapat didaftarkan. Dan di belakang nama, sehingga memiliki otoritas hukum yang sempurna.Melakukan proses jual beli tanah dihadapan PPAT akan memiliki kekuatan hukum dan sah, serta perlindungan hukum bagi para pihak juga telah tercantum di dalam akta yang dibuat dihadapan PPAT. Ini juga dapat mencegah perselisihan di antara para pihak, terutama mereka yang tidak memahami pentingnya membeli dan menjual tanah sesuai dengan hukum yang berlaku.Namun jual beli di bawah tangan tidak memiliki kekuatan hukum yang sempurna bagi para pihak yang melakukannya.

\section{Saran}

Berdasarkan hasil penelitian ini, beberapa hal yang disarankan ke berbagai pihak, meliputi; pemerintah setempat diharapkan memberikan petunjuk dan pengarahan kepada masyarakat setempat mengenai lemahnya kekuatan hukum jual beli tanah di bawah tangan, dan sebaiknya melakukan jual beli tanah dihadapan pejabat yang berwenang atau PPAT. Kemudian untuk PPAT, supaya aktif memberikan sosialisasi rutin, untuk meningkatkan kesadaran masyarakat melakukan jual beli tanah harus dihadapan PPAT. Terlebih kepada Masyarakat di harapkan melakukan transaksi jual beli di hadapan PPAT sehingga pemerintah dapat memberikan perlindungan dan kepastian hukum dalam pelaksanaan jual beli tanah hak milik tersebut

\section{DAFTAR PUSTAKA}

Afriyandi, T. (2018). Kewenangan Pemerintah Daerah dalam Menentukan Harga Jual dalam Transaksi Jual Beli Tanah dan atau Bangunan. Jurnal Hukum Volkgeist, 1(2), 28-40.

Badoa, M. D., Kapantow, G. H. M., \& Ruauw, E. (2018). Faktor-Faktor Penyebab Alih Fungsi Lahan Pertanian di Kecamatan Tomohon Selatan Kota Tomohon. Agri-SosioEkonomi Unsrat, 14(2), 195-204.

Fajaruddin. (2017). Pembatalan Perjanjian Jual Beli Hak atas Tanah Akibat Adanya Unsur Khilaf. De Lega Lata, 2(2), 285-306.

Faranzenia, A., Wiryomantani, W., \& Suryandono, W. (2019). Tanggung Jawab Notaris dalam Pembuatan Akta Jual Beli Berdasarkan Perjanjian Pengikatan Jual Beli Lunas yang Hasil Pembayarannya Dikembalikan Kepada Pihak Pembeli (Studi Kasus Putusan Majelis Pengawas Pusat Notaris Nomor 04/B/MPPN/VII/2019). Notary Indonesian, 1(4), 1-21.

Harefa, B. D. S., \& Tuhana. (2016). Kekuatan Hukum Perjanjian Lisan Apabila Terjadi Wanprestasi (Studi Putusan Pengadilan Negeri Yogyakarta Nomor 44/PDT.G/2015/PN.YYK). Privat Law, IV (2), 113-122.

Hayati, N. (2016). Peralihan Hak dalam Jual Beli Hak atas Tanah (Suatu Tinjauan terhadap Perjanjian Jual Beli dalam Konsep Hukum Barat dan Hukum Adat dalam Kerangka Hukum Tanah Nasional). Lex Jurnalica, 13(3), 278-289.

Pramono, D. (2015). Kekuatan Pembuktian Akta yang Dibuat oleh Notaris Selaku Pejabat Umum Menurut Hukum Acara Perdata di Indonesia. Lex Jurnalica, 12(3), 248-258.

Rismayanthi, I. A. W. (2016). Tanggung Jawab Pejabat Pembuat Akta Tanah (PPAT) terhadap Pendaftaran Peralihan Hak Atas Tanah yang Menjadi Objek Sengketa. Jurnal Ilmiah Prodi Magister Kenotariatan, 1(1), 2016.

Saranaung, F. M. (2017). Peralihan Hak Atas Tanah Melalui Jual Beli Menurut Peraturan Pemerintah Nomor 24 Tahun 1997. Lex Crimen, 6(1), 13-21.

Soekanto, S. (2007). Pengantar Penelitian Hukum. UI Press.

I Gusti Agung Surya Kusyanta, SH, Responden Pembeli, Wawancara pribadi, Denpasar, 03 Januari 2020, pukul 13.05 WITA. 